\title{
Introduction: Opening Public Spaces
}

\section{Sebastian Veg}

\section{OpenEdition}

\section{Journals}

Electronic version

URL: http://journals.openedition.org/chinaperspectives/5047

DOI: 10.4000/chinaperspectives.5047

ISSN: 1996-4617

Publisher

Centre d'étude français sur la Chine contemporaine

\section{Printed version}

Date of publication: 21 April 2010

ISSN: 2070-3449

Electronic reference

Sebastian Veg, «Introduction: Opening Public Spaces », China Perspectives [Online], 2010/1 | 2010,

Online since 01 April 2013, connection on 23 September 2020. URL : http://journals.openedition.org/ chinaperspectives/5047 ; DOI : https://doi.org/10.4000/chinaperspectives.5047

(c) All rights reserved 


\title{
Introduction:
}

\section{Opening Public Spaces}

\author{
SEBASTIAN VEG
}

$\mathrm{O}$ ne may well wonder why a journal devoted to contemporary Chinese politics and society would choose to publish a feature on Chinese cinema of the last two decades. Many young independent directors have on the contrary been intent on highlighting the artistic quality of their work rather than its political significance. Their films have been badly distributed and irregularly circulated in China; they cannot even be considered an element of the cultural consumption patterns of a possibly emerging new urban middle class. Their larger significance - if any - lies therefore not in numbers, but in the very phenomenon of their emergence and continued development, despite their numerically small impact, at a turning point in the history of cultural production in contemporary China.

What is meant by independent cinema in China? As noted earlier, we have chosen to use the term "independent" preferred by the directors most commonly associated with the movement. ${ }^{(1)}$ This is the title chosen for the book that marked their strongest assertion of collective existence to date, edited by former Jintian poet Ouyang Jianghe, which under the title Zhongguo duli dianying: Fangtan lu (Chinese Independent Cinema: A Collection of Interviews), and the English subtitle On the Edge: Chinese Independent Cinema, brought together interviews with ten directors: Jia Zhangke, Wang Chao, Li Yang, Li Yu, Zhang Ming, Lou Ye, Zhu Wen, Pema Tseden, Li Hongqi, and Han Jie. (2) While some of them were earlier referred to as "the Sixth Generation," they rejected this label and sought to underscore their break with the system of generational "transmission" of a shared heritage handed down to the Fifth Generation of the 1982 graduates of Beijing Film Academy. In addition to the break in tradition, the idea of "independence" also marked a concrete separation from the state-sanctioned production and distribution system, which even after the deep-cutting reforms of 1996-1997 remains under the threefold auspices of the China Film Group or CFG (Zhongguo dianying jituan gongsi or Zhong Ying), ${ }^{(3)}$ the State Administration of Radio, Film and Television or SARFT (Guojia guangbo dianying dianshi zong ju, also known as Guang dian ju or Dianying ju for short) and the Central Department for Propaganda of the Chinese Communist Party (CCP), the latter two of which jointly implement the censorship system. ${ }^{(4)}$ However, this form of independence does not appear to be a central tenet of how they view their work: both Zhang Yuan with Seventeen Years (Guonian huijia) in 1999 and Jia Zhangke with The World (Shijie) in 2003 chose to enter the official circuit to bring their films to a larger audience; other directors offered this opportunity would no doubt make the same choice, and many have collaborated with state-run studios on an ad-hoc basis. ${ }^{(5)}$ This choice implies that the term "independent," although of course referring to the aesthetics of "indie" productions on an international level, is not understood by the directors themselves as a way of placing themselves outside the space of contemporary China, for example by making films primarily for the international festival circuit, as they are often "accused" of. Although it is always possible for critics to question their motivations, ${ }^{(6)}$ it should be noted that most of these directors claim to be

1. A similar choice is explained in the "Preface" of: Paul Pickowicz, Yingjin Zhang (eds.) From underground to independent: Alternative film culture in contemporary China, Lanham, Rowman \& Littlefield, 2006, pp. vii-xi.

2. Hong Kong, Oxford Books, 2007; the book was simultaneously published as a specia issue of Jintian.

3. CFG owns a long list of subsidiaries, among which: the China Film Import and Export Corporation (Zhongying dianying jinchukou fen gongsi), Huaxia Distribution Ltd. (Huaxia dianying faxing youxian zeren gongsi), and several state-run studios. An (impressive) list of subsidiaries is available at http://www.chinafilm.com/gzzy/congci/20070204/ 2112.html. (20 February 2010).

4. There are currently two stages of verification by the censorship system in the case of feature films: a 1,500-word synopsis must be approved before authorisation is given for shooting by one of the regional film offices; after post-production, the edited film must pass the central SARFT censorship committee for approval. It must also obtain a quota number from a Film Studio, but these can usually be purchased for a fee. See: Liu Wei: "Censoring Movies done according to script" (interview with Zhang Hongsen), China Daily, 31 August 2007, p. 14. It should be noted that 1) SARFT no longer requires submission of a full-length script in order to issue initial approval for filming since 2006, and 2) SARFT has never had a specific procedure for approving documentary films (which do not have a script) made outside the television production system, a loophole fruitfully exploited by the New Documentary movement.

5. See Valerie Jaffee, "Bringing the World to the Nation: Jia Zhangke and the Legitimation of Chinese Underground Film," Senses of Cinema, no. 32 (July-September 2004), http://archive.sensesofcinema.com/ contents/04/32/chinese_underground_film.htm (20 February 2010).

6. Yingjin Zhang, for example, deems their independence "dubious" in "Rebel without a cause" in Zhang Zhen (ed.), The Urban Generation, Durham, Duke University Press 2007, p. 54. Jason McGrath, in the same volume, notes in passing that "the sensationalised marketing in the West of independent Chinese cinema as 'banned in China!' is an undeniable phenomenon symptomatic of a lingering cold war cultural discourse" ("The Independent cinema of Jia Zhangke: From postsocialist realism to a transnational aesthetic," ibid., p. 108). See also Yingjin Zhang, "My camera doesn't lie?" in Y. Zhang and P. Pickowicz, From Underground to independent, op. cit., p. 23-46. 
Ouyang Jianghe (ed.), Zhongguo duli dianying: Fangtan lu, Hong Kong, Oxford University Press, 2007. producing films for a Chinese audience, and situate their production within the intellectual and aesthetic debates of contemporary China.

The prolific activities of this loose group of directors have been sketched out many times, and there is no need to dwell on the timeline of their major productions. However, critics and academics remain hesitant about how to characterise the core of their common interests or aesthetics in order to discuss them collectively. As has been noted, two "waves" of directors can be distinguished within this group: the first, born mainly in the mid-1960s, began making films in the immediate aftermath of the Tiananmen protest movement of 1989 - Zhang Yuan (born in 1963), Lou Ye (1965), Wang Xiaoshuai (1966) and Guan Hu (1967) were its main exponents at the beginning of the 1990s. Earlier yet, in late 1989 and early 1990, Wu Wenguang (born in 1956), shot the first film of what would later be called the New Documentary movement (Xin jilu yundong): Liulang Beijing (Bumming in Beijing). Recording the lives of four "drifters" afloat in the city after the events of June Fourth, in a vein that was followed by Zhang Yuan with Beijing zazhong (Beijing Bastards) in 1993, Wu firmly established the original link between independent film and the repressed protest movement. ${ }^{(7)}$ In the aftermath of the unsuccessful demands for institutional reform by urban intellectuals, students, artists, and workers in 1989, many of the disillusioned sympathisers of the movement turned to soul-searching on the root causes of their failure. Criticism of the intellectual elite and lack of "cultural democratisation" reaching further down to the grassroots of Chinese society were pinpointed. It was in this context that Wang Xiaobo's incisively critical essays gained currency, calling for greater attention to the "weak groups" (ruoshi qunti) representing the "silent majority" (chenmo de daduoshu) of Chinese society, and to understand the grievances and dissatisfaction of this silent majority with the system on its own terms. ${ }^{(8)}$ Like the May Fourth "turn to culture" as a vector for in-depth democratisation after the failure of 1911, the turn to cultural production represented by independent film can be seen as a (pale) substitute for greater democracy in politics. At the same time, by striving for a more "democratic" approach to film, independent directors also made it into a space for reflection on the disenfranchisement of those who had been bypassed by the movement, and thus for rethinking the notion of democracy itself.

The second group of directors, which appeared about ten years later at the end of the 1990s, although not directly linked with Tiananmen, shared the first group's concern for

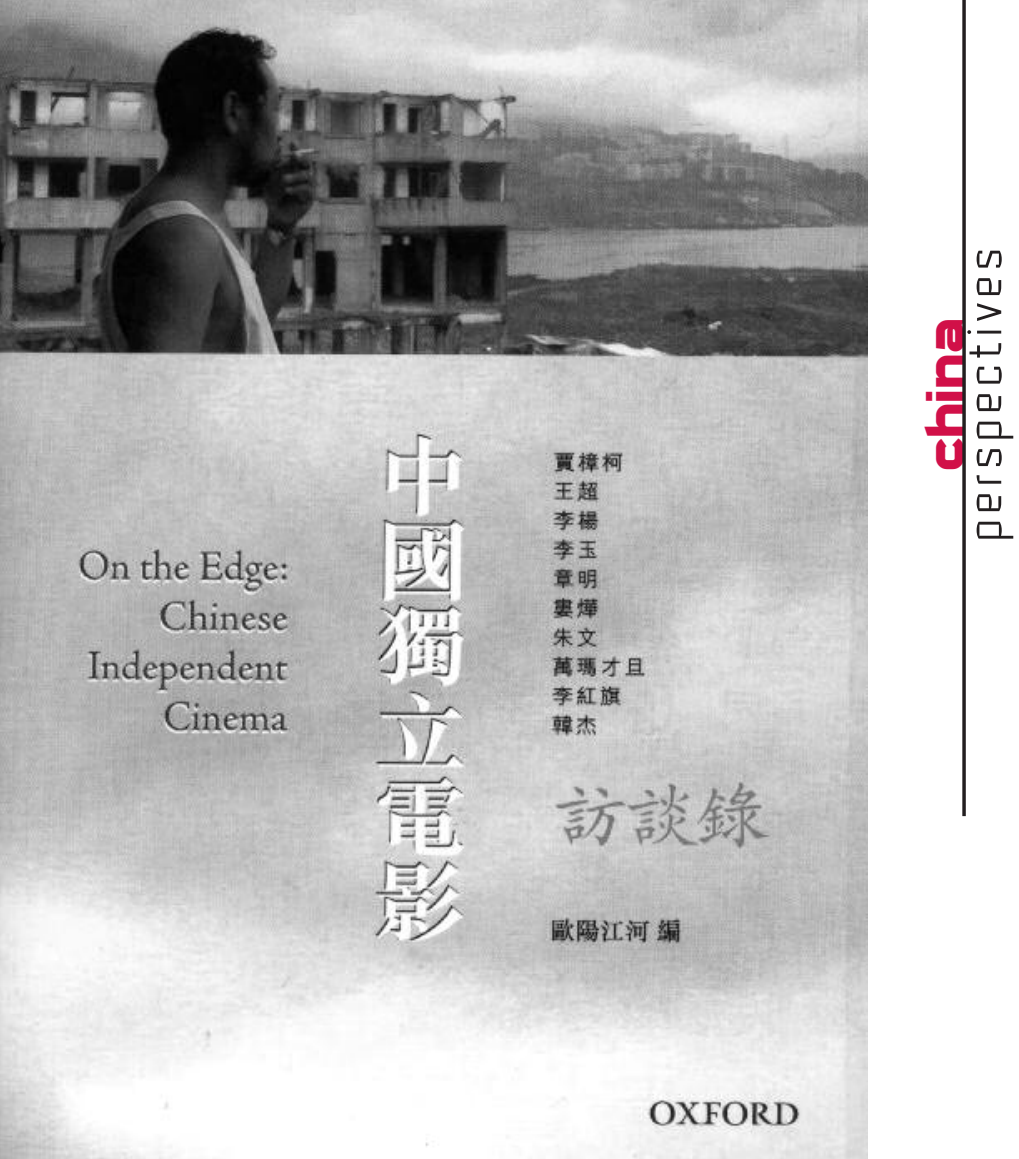

the "margins" and the "weak," expressed by the newly fashionable post-class society term of "diceng" ("lower strata"). Jia Zhangke (born in 1970), Du Haibin (1972), and the slightly older Wang Chao (1964) and Wang Bing (1967), all turned their cameras away from big cities and towards ordinary lives in China's countless remote industrial countytowns. After a decade of work by the New Documentary movement, this "second wave" of directors drew even more heavily on documentary aesthetics, effectively crossing over, if not blurring, the line between documentary and feature. Jia Zhangke became the highly articulate spokesperson of the new aesthetics when he published two short but widely circulated essays in 1998: "The Age of Amateur Cinema is About to Return" (Yeyu dianying shidai jijiang zaici daolai) and "Now that We Have VCDs and Digital Video Cameras" (You le VCD he shuma shexiangji yihou). In these articles, the former of which was published by the influential Nanfang Zhoumo (Southern Weekend) in 1999, Jia argued

7. Chris Berry effectively highlights the "June Fourth issue" as "the structuring absence at the heart" of the early New Documentaries in "Getting Real," The Urban Generation, op. cit., p. 119 .

8. Zhang Yuan and Zhu Wen, in particular, were personally close to Wang Xiaobo and his wife Li Yinhe until Wang's premature death in 1997. The most famous product of their collaboration is Zhang Yuan's film East Palace, West Palace, adapted from Wang's short story "Tender as water" (Sishui rouqing), also related to Wang and Li Yinhe's study of male homosexuality in China, first published as Tamen de shijie (Their world) in 1992. See Chris Berry, "Staging Gay Life in China: Zhang Yuan and East Palace, West Palace" in Tan See-kam, Peter X. Feng and Gina Marchetti (eds.), Chinese Connections: Critical Perspectives on Film, Identity, and Diaspora, Philadelphia, Temple University Press, 2009, pp. 165-176. 
that technical progress had entailed a radical democratisation both of film-viewing (VCD) and film-making (DV cameras), in an unexpected development that the authorities were unable to control. This digital revolution with as yet unknown consequences could be seen, in some ways, as an ironic revenge of history for the repressed democracy movement of 1989. In an interview carried out that same year, Jia described himself as "an unofficial director from the grassroots of Chinese society" (yige laizi Zhongguo jiceng de minjian daoyan). By giving this title to a long interview first published in Jintian (1999, no. 3), the journal founded by Bei Dao in 1979 and intimately connected with the history of dissidence in the 1980s (published abroad after 1989), Jia tellingly subordinated national identity (Zhongguo), often deemed central in the cinema of the 1980s, to the "grassroots" (jiceng) identification of an ordinary person, an "unofficial" (minjian) director, whose work is not justified by his status or qualification, an "amateur" (уеyu) in the noblest sense of the word. ${ }^{(9)}$

The earliest scholarly attempts to characterise the coherence of this body of documentary and fictional work usually resorted to various notions of "realism." Realism is, at best, a slippery concept, and is often used in confusing or contradictory ways. ${ }^{(1)}$ Realism had been claimed by officially-produced propaganda films from 1949 onwards, although it was later adapted to accommodate the "revolutionary romanticism" advocated by Guo Moruo. It was again claimed by the Fifth Generation directors in their exploration of the "real," rural China, where the cultural roots of the nation lay dormant, awaiting rediscovery, almost unscathed by the political violence of the second half of the twentieth century. While it is quite true, of course, that independent Chinese directors resorted to a "gritty" seemingly "unedited" imagery concentrating on aspects of reality not previously highlighted in Chinese film, the characterisation as "realism" seems unsatisfactory. Jason McGrath's careful qualification of Jia Zhangke and Zhang Yuan's work as "postsocialist critical realism" remains somehow unsatisfactory, as he applies the same label to Zhang Yimou's film Qiu Ju, adding that "While the Urban Generation directors in the 1990s hoped to distance themselves from their Fifth Generation predecessors in general, The Story of Qiu Ju nevertheless helped to set a new standard for realist techniques in Chinese fiction film." (II) This somehow misses the point of Jia Zhangke's and others' rejection of the Fifth Generation aesthetics, which remains closely in line with the modernising Chinese nation-state.

Evans Chan's discussion of Qiu Ju is helpful in eliciting this point. Noting that Qiu Ju and Not One Less were ac- claimed abroad and that "Zhang was hailed as an authentic successor to Italian neorealism" while at the same time eliciting the praise of the CCP's Propaganda Department chief Li Ruihuan, Chan begins by quoting Jonathan Spence's discussion in The New York Review of Books, in which the government officials in the film are described as follows: "These men - for they are all men - are presented without exception as being courteous and kindly, ever receptive to a simple peasant woman's right to complain. they are clean and neat and gentle. They never take bribes or even accept presents [...]. Surely to most Chinese in the PRC, and to any Westerners who have had business there, this presentation appears absurd, a mocking echo of all those legions of selfless 'model cadres' who have filled Communist plays, films, and fiction since the 1930s." ${ }^{(12)}$ Chan concludes that Zhang's realism produces the following effect: "What has been subtly 'naturalized' is a benign bureaucracy's interaction with its citizens, achieved through Zhang's 'anti-art, documentary' approach. The authoritarian state is ultimately humanized by its gentle servants and its final concern for justice, which brings us to the precise moment when its citizens feel chagrined by their insistence on justice." (13) Zhang Yimou's film, while using realist, even cinema-vérité aesthetics, remains firmly within the framework of "critical realism" first developed in the 1920s: a pre-scripted discourse criticising deviant elements to strengthen the nation-state and the Party that underpins it. To quote an example from a director close in age to Zhang Yimou but who became active only within the context of "independent" film: Li Yang's Blind Shaft (2003) is an eloquent example of how similar subjectmatter is narrated within a context where there is no overarching narrative to make sense of the absurdity of a coal-mine murder, an event both fictional and closely related to reality. Similarly, Jia Zhangke has repeatedly stressed that realism is not his primary concern. In the discussion published in the present issue, he quotes Krzysztof Kieslowski to assert that "the closer you stick to reality, the more absurd and unreal the film becomes." In a dialogue with Du Haibin, he makes a similar point when saying: "Fiction is also a bridge to truth

9. Jia Zhangke has repeatedly underlined that his use of the word "amateur" refers to a mind-set in approaching his subject-matter, not to the technical quality (or lack thereof) of the films gathered under this label.

10. For a variety of definitions, see Roman Jakobsen, "On Realism," in Krystyna Pomorska and Stephen Rudy (ed.), Language in Literature, Cambridge (MA), The Belknap Press, 1987, pp. 19-27.

11. J. McGrath, "The independent cinema of Jia Zhangke," art. cit., p. 85.

12. Jonathan Spence, "Unjust Desserts," The New York Review of Books, 24 June 1993.

13. Evans Chan, "Zhang Yimou's Hero: The temptations of fascism," in Chinese Connections, op cit., p. 267. 
[zhenshi]. Including our understanding of it - how it happens, how it becomes real; what are its levels? Truth itself is a kind of experience, a kind of judgment, not a style of documentary-making. That is why, in my documentaries there are many arranged shots, I make up a lot, and I use actual people to act." ${ }^{(14)}$ Therefore repeated stylistic references to Bazin's cinema-verité realism and Deleuze's "time-image" don't highlight what makes independent film different from its predecessors. Chris Berry, who sums up the new cinema under "the imperative to 'get real'," therefore takes care to outline that this imperative refers not only to realism (whether of the old xianshi zhuyi or the new xieshi variety, also referred to by Chris Berry as jishi zhuyi) but "also to the slang phrase 'wise up' or 'stop dreaming." (15) If realism is to be preserved as an analytical category, it therefore probably calls for further refinement.

Zhang Zhen, in the 2007 edited volume in which Berry's and McGrath's articles appear, proposes to characterise independent cinema using the new paradigm of an "Urban Generation." The Urban Generation refers to "works centered on the experience of urbanization by young filmmakers who emerged in the shadow both of the international fame of the Fifth Generation directors and of the suppressed democracy movement in 1989." (16) Their works thus define an aesthetics marked by ruins, destruction, and (sometimes) rebuilding, mass migration to the cities, poverty, and despair. ${ }^{(17)}$ This rich and polyphonic publication marks an important attempt to move beyond general characterisations in terms of "realism" or "underground." However, when looking at the films we consider most representative of this movement - Jia Zhangke's "Hometown Trilogy" or Still Life, Wang Bing's West of the Tracks, Li Yang's Blind Shaft, Wang Chao's The Orphan of Anyang, Li Yu's Dam Street, Zhu Wen's Seafood, it seems difficult to characterise this cinema as overwhelmingly urban. Many of the spaces featured are county-towns such as Jia Zhangke's Fenyang or Datong, Wang Chao's Anyang, or huge industrial complexes that have developed into small towns unto themselves such as Tiexi District in Shenyang, or even smaller, more remote settings ( $\mathrm{Li} \mathrm{Yu}, \mathrm{Zhu}$ Wen). It is true that some works are indeed devoted to the metropolises of Beijing (Ning Ying's Beijing Trilogy, Li Yu's Lost in Beijing) or Shanghai (Lou Ye's Suzhou River). However, the notion of an "urban cinema," with its visions of pre-war Shanghai, Wong Kar-wai's Hong Kong, or Tsai Ming-liang's Taipei, may be somewhat misleading, although it is true that independent film definitely breaks with the rural, predominantly natural landscapes of the Fifth Generation, suggesting that "urban" here essentially refers to "non-rural." ${ }^{(18)}$ It could be further underlined that in the latest developments over the last five years, new works by the youngest generation of independent directors, born in the late 1970s and early 1980s - Yang Jin's (born 1982) Er Dong, Peng Tao's (1974) Little Moth, Robin Weng's (1982) Fujian Blue - take this aesthetic of public space back out into the purely rural environment of China's villages, in a complete reversal of the values exemplified by Fifth Generation films.

More importantly, Zhang Zhen herself suggests that the urban paradigm is better understood as "a critical category that places film practice right in the middle of a living, if often agitated, social, cultural and political experience." ${ }^{(19)}$ She also underlines the importance of the aesthetics of xianchang (rendered as "on the scene"), with its ambiguous reference to both the "real" scene and the film set. The core idea here is actually that of public space: both as the object of film (which is related to an urban context in the sense that it belongs to the polis, as opposed to contemplation of nature) and as the space in which cinema situates itself as a public activity. The notion of public space in the present article refers to the sense, defined by Jürgen Habermas, of a space that opens up the sphere of general discussion by ordinary citizens because it is no longer monopolised as a "space of public violence." ${ }^{20)}$ The last scene of Xiao Wu epitomises the space in which independent cinema takes place: a street scene in a small town, in which the protagonist is chained to an electric pole by the police, who are arresting him for theft. In a vein reminiscent - as highlighted by Jia Zhangke himself ${ }^{(21)}$ - of the gaping crowd at the exe-

14. “Jia Zhangke vs. Du Haibin”, Mingpao Weekly, 28 November 2009, p. 48.

15. Chris Berry, "Getting Real: Chinese documentary, Chinese postsocialism" in Zhang Zhen, op. cit., p. 115. However, the imperative to "stop dreaming" does not seem to be a good description of Jia Zhangke's films, for example, which are often dedicated to the aspirations, dreams, and fantasies of his protagonists.

16. Zhang Zhen, "Introduction. Bearing Witness: Chinese urban cinema in the era of "transformation" (zhuanxing)," in The Urban Generation, p. 1.

17. An interesting discussion of the aesthetics of ruins is Wang Hui's essay "Jia Zhangke de shijie yu Zhongguo de da zhuanxing" (Jia Zhangke's world and the great transformation of China), originally published in Renwen yu shehui (Humanities and society) and widely available online, for example via the following link: http://www.chinesethought.org/whyj/003191.htm (25 February 2010).

18. There are also other reasons for reservations about the "urban" label. Chris Berry, in an article published in 1988, already used the category of "Chinese urban cinema" to compare two Fifth Generation directors, Zhang Liang and Huang Jianxin (East-West Film Journal, vol. 3, no. 1, 1988, pp. 76-87). Zhang Yingiin, in his contribution to Zhang Zhen's volume, similarly includes Chen Kaige in his discussion of "urban filmmakers" (The Urban Generation, p. 70), although Chen is the epitome of what the independent generation is rejecting.

19. Zhang Zhen, "Introduction. Bearing Witness," art. cit., p. 8.

20. Jürgen Habermas, Strukturwandel der Öffentlichkeit, Frankfurt, Suhrkamp, 1990 [1962], p. 84.

21. See Michael Berry, Jia Zhangke's Hometown Trilogy, Houndmills, Palgrave / British Film Institute, 2009, pp. 46-47. 
cution scene of The True Story of $A h Q$, more and more passers-by stop to gape at the handcuffed $\mathrm{Xia}_{\mathrm{iao}} \mathrm{Wu}$, but among all the onlookers, not one speaks out to question the legitimacy of his arrest. This scene, which is as fundamental to independent cinema as the execution scene on the slide for Lu Xun, effectively demonstrates that one of the central questions of new independent film is the integration of the individual within various public collectives, often visualised by the use of common spaces such as factories, train or bus stations, street forums, collective living quarters, or factory bathhouses: the many xianchang in which individuals are confronted with the collectives in which their lives take place.

The notion of a xianchang aesthetic is important, as the notion was used in one of the earliest attempts made by Chinese directors to bring together their work under one heading. Wu Wenguang published three volumes of what was presented as a journal, Xianchang (English subtitle: Document) in 2000, 2001, and 2005. Organised by "files" (dang'an), with the explicit aim of documenting the new cultural practices without limiting them within any preconceived or narrowly genre-oriented definition, the first volume contains the entire screenplay of Jia Zhangke's $X i a o W u$, as well material related to Kang Jianning's documentary $Y$ in Yang; volume two dedicates a "file" to Du Haibin's Along the Railway. These works are thus situated within a larger group of literary, artistic, and more largely cultural productions such as oral history. What they share is not spelled out, but is suggested by the eclectic juxtaposition: xianchang refers to a reversibility between the real scene and the film set, documentary and fictionalisation, codified cultural practices and the most ordinary kind of narratives told by migrant workers, and labelled "oral history."

How then does xianchang tie in with public space? What is meant by the two terms? The notion of public space as put forward by Habermas is problematic even in its original context, and all the more so in present-day China. Does it refer to actual spaces, such as the salons and cafés originally quoted as examples by Habermas (and recently criticised by historians), in which "publicity" of debate depended on the private status of the space, or simply to a discursive space of "shared humanity" or of an "imagined community" in which each individual is free to air an opinion on matters of public significance? The latter meaning is certainly applicable to independent cinema, in that, based on the assumption of a common humanity shared by the objects of filming, the director behind the camera, and the audience on the other side of the screen, it strives to bring into existence a discus-

sion on the common values of society that does not simply replicate the discourse promoted by the state through education and government-sponsored art. ${ }^{(22)}$ However, cinema, as a spatial medium, also gives physical shape to this discursive space. The present paper hypothesises that independent cinema, in keeping with Wang Xiaobo's preoccupation with "weak groups" and "the silent majority," has sought to provide visual images of how the private stories of ordinary individuals are shaped in public spaces, spaces in which they are subjected to the public gaze and the great institutions that control modern life, but in which they try to give voice to their individual values. This space can also be described as the "unofficial" space referred to in Chinese as minjian (the "space of the people"). In this sense, the aesthetics of xianchang is destined to capture on screen the spatial materialisation of a public sphere where alternative discourses are not silenced and where, in the long term, a form of "public consciousness" can be formed, in the words of Jia Zhangke. In the dialogue transcribed in the present issue, Jia Zhangke highlights that his engagement with film stemmed not from a sense of responsibility toward society, but from the urge to express himself, to tell individual, private stories, just as Teresa Teng sang in the first person - a viewpoint replicated by many independent directors, who routinely stress that their films are about their parents, their family, their neighbours, their friends. In an historical perspective, after a period during which public space in the Habermasian sense disappeared altogether in China, these films materialise a moment in which ordinary individuals - and Jia Zhangke's preferred actor Wang Hongwei, as Xiao Wu and his avatars, embodies extreme ordinariness - can once again tell their private stories in public or, to put it differently, question the collective narratives that dominate the political sphere (modernisation, nation-building) in the name of their individual stories. Here the contrast with Fifth Generation directors becomes apparent: the post-1989 independent films refuse the tenet of representativity or symbolism that pervades the cinema of the 1980s. Qiu Ju, as has been remarked, is not an individual, but the "larger-than-life icon of the repressed

22. A similar approach has been followed to analyse a different group of films by Stephanie Donald in Public Secrets, Public Spaces: Cinema and Civility in China, Lanham, Rowman and Littlefield, 2000. 
peasant woman"; whereas the migrant worker, "unlike the timeless cipher of Gong Li, is hardly an icon for a "national cinema." (23) In this way Jia Zhangke, no doubt influenced by Zhu Wen's earlier feature South of the Clouds (Yun de nanfang), conceived of 24 City as a film that would tell the individual stories of people caught up in the system of Maoist nation-building through industry, in which entire towns of people could be displaced from one end of the country to the other, sometimes losing children on the way. To put it in yet another way, emerging from a period when all purely private stories were irrelevant, independent post1989 films are engaged in reinventing a public meaning for individual stories, based on a common humanity rather than on inserting the individual into the grand narratives of the modern state. This is one way of reading Wang Bing's West of Tracks, as a search for individual meaning after the demise of the collective. It is also the essence of the confrontation between the policeman doing his duty and the man he has arrested and who tries to reverse the balance of power by seductively telling the policeman his own story, in one of the earliest films of the movement, Zhang Yuan's East Palace, West Palace. In any case, there is no preconceived significance to the individual's story - whether this story is a factually recorded or a fictionally created one.

Ning Ying's films - although she is a 1982 graduate of the Beijing Film Academy - can also be situated within this aesthetic, as she underlined in a discussion that it is worth quoting at length:

In the 1990s, I shot the Beijing Trilogy - these three films were shot entirely on the street, in a true space, shooting three generations of people and their stories, their background. The trilogy was about the relations between these three generations of individuals and the system. Perhaps for you, it might be simple to classify these films as belonging to public space. However, they were made with an important goal: to show that within the film system, there was nothing - no characters, no stories, no spaces - that we could identify with at the time. On the surface I was also describing society, the open space. But the people I looked at were completely different; these were people who had never appeared in the official media, people who were nursing their wounds. There was something deeply subversive about showing these characters, something like Wang Shuo's writing, which was contradictory to the Chinese people that mainstream society hoped to see on screen. [...] In a way, we are always fighting for a kind of right, the right to creation. This is a basic human right that is often overlooked, because when discussing human rights we talk about very vague ideas. So when making a film, 50 percent of my time is devoted to gathering the necessary capital, but another 50 percent is devoted to allow what I show, what I like to call the "real space" or what you might call a "real private space," to allow this space to enter into a direct dialogue with the public space we can see. Only in this way can film have a more subversive use, and thus have a greater social, cultural, artistic, and political use within society. [...] And for me, women's films were a way of standing outside the system, in which there were only male directors, to look at characters who were outside the lens angle of other people's camera. ${ }^{(24)}$

Ning Ying therefore also stresses the importance of telling individual stories of ordinary people "outside the lens" (and women can be seen as one of the largest "weak groups" mentioned by Wang Xiaobo), not pre-empted by an aesthetics of representativity, but nonetheless situated within a public space and a space for public discussion. Therefore, the xianchang can be described as the scene where this encounter happens, and where, indeed, anything can happen. In this sense, the argument developed in this issue is that independent cinema can be defined by its recurrent exploration of public spaces, and of the individuals within them.

At this level, the question of reality is crucial, and Jia Zhangke has repeatedly highlighted in his interviews that reality, in particular the reality of spaces, plays the role of a matrix for his films, including for their most "unrealistic" aspects. Observing a space, and the way an individual moves in it, is one of his sources of inspiration, as he highlights in his short essay on the documentary In Public included in this issue. In the discussion on "public consciousness," Jia Zhangke goes so far as to hypothesise that long takes are a "democratic form" in that they do not impose a narrative on the protagonist, real or fictional, but allow him or her to move and develop freely; nor do they impose a reading on the audience, by leaving some room for superfluous images within the tightly edited structure of a commercially distrib-

23. Zhang Zhen, art. cit., pp. 3 and 6

24. This statement by Ning Ying is transcribed from a panel discussion held on 12 April 2009, which could unfortunately not be published in its complete version in this issue. The audio file is available online at: http://www.cefc.com.hk/rubrique.php?id= 138\&aid=367 (21 February 2009). 
uted film. Therefore, if independent Chinese film is engaged with a form of realist aesthetic, it can only be a realism of contingency, as argued by Luke Robinson, in which the primacy of the xianchang dictates the progression and structure of the film. ${ }^{(25)}$ Reality is unpredictable, and only by capturing its randomness can the director be true to the individuals who populate it and whose stories he is telling. In a sense, a supreme form of violence can be discerned in the narrative structures that make historical contingencies - and the pain they can inflict on individuals - into necessities driven by the progress of history. Hence, one might argue that certain works of independent cinema are perhaps more indebted to the formal experiments of the Soviet avant-garde than to Italian neo-realism. In this sense, the accent placed on an aesthetics of contingency is also a radical critique of the linearity of historical development, which is probably not unrelated to China's present situation. ${ }^{(26)}$

In conclusion, it should be underscored that the xianchang in which individual stories insert themselves into public space is also a metaphor for the position independent cinema aims to occupy. Independent film, since its inception in a tightly controlled post-Tiananmen public sphere, has itself become increasingly public, in one sense, by creating its own spaces. Cinema - like other forms of art, as remarked by Hannah Arendt ${ }^{(27)}$ - is always about bringing a private story into the public domain. However, by developing an independent set of values, based on a particular aesthetics grounded in an ethics of representation, independent Chinese cinema opened up its own discursive space for discussion. As hypothesised by Habermas, the relative autonomy of the aesthetic sphere and the informed but open discussion this autonomy permits, can advance the formation of public spaces that may become available for other purposes. It is remarkable that while independent Chinese film might have developed in the direction of ever greater privatisation, especially with the sudden availability of low-price home video described by Jia Zhangke, the independent films have always found their way into public performances. Legitimated by the prizes or simply the praise they have won in international festivals, directors have been able to re-import this prestige into a domestic context and to use it as leverage. Jia Zhangke enthusiastically describes at length the birth of countless film clubs in medium-sized cities all over China in the 1990s, and their organisation of VCD and DVD screenings in cafés, university facilities, art spaces, or exhibitions. ${ }^{(28)}$ Internet, video posting sites such as Tudou and Youku, and social groups such as Douban, greatly enhanced the circulation of information. Then came full-fledged inde- pendent festivals: the Yunfest devoted to documentary held in Kunming every two years from 2003, the China Independent film festival in Nanjing held yearly since 2004, the Beijing Independent Film Festival held in Songzhuang (under the joint auspices of Li Xianting's film fund and Zhu Rikun's Fanhall distribution website) yearly since 2006, joined in 2009 by the China Independent Film Archive festival held in the Iberia Art Centre in Beijing's 798 art district. The last five years have seen an exponential increase in independent films made by ordinary people in far-flung towns all over China, which have found their way into festivals and theatres. As this issue goes to print, Beijing's first "arthouse cinema" has been opened in the MOMA complex by the Hong Kong-based Broadway circuit.

However, it is important to avoid the teleology of an ever more "public" form of cinema in China. For one thing, regulations remain unpredictable. But more fundamentally, as underlined in Luke Robinson's essay, the meaning of "public" and "private" itself is ambiguous. While "public documentaries" in his analysis refer to films prepared for screening on public television within the constraints of the public system, "private documentary" (the example given is Wang Bing's West of the Tracks), represents a higher degree of freedom from the constraints of coherent editing and narrative. Considered from this angle, the trend of independent film has also been toward ever stronger "privacy." Recent films by the young female director Liu Jiayin, Oxhide and Oxhide II, revert entirely to the intimate sphere of the home, symbolically eschewing any confrontation with the gaze of the public. In this sense, the space of "publicity" independent film has been able to "open up" in the last decade remains not only very limited but also ambiguous as to its own subjective governing principles. Yet it is perhaps this ambiguity itself, its fleeting, always endangered status of an uninstitutionalised space, which gives it the burning urgency of the present (the xianchang) that undoubtedly represents an incomparable appeal to its ever-growing audience.

-

25. Luke Robinson, "Contingency and Event in China's New Documentary Film Movement," Nottingham University, p. 27.

26. See also my discussion in "From Documentary to Fiction and Back: Reality and Contingency in Wang Bing's and Jia Zhangke's films," China Perspectives no. 2007/3, p. 136.

27. Hannah Arendt, The Human Condition, Chicago, University of Chicago Press, 1998 [1958], p. 50.

28. See also Seio Nakajima, "Film clubs in Beijing: the cultural consumption of Chinese independent films," in Paul Pickowicz, Yingjin Zhang, From underground to independent, op. cit., pp. 161-188. 